\title{
Analysis of the relationship between job satisfaction and organizational trust of physical education and sports teachers
}

\author{
Murat Aygün \\ Ardahan University, School of Physical Education and Sports, Turkey
}

\begin{abstract}
Job satisfaction and organizational trust emerge as just two of the important factors that can lead all institutions to success today. The objective of this research is to analyse, the relationship between job satisfaction and organizational trust of physical education and sports teachers pursuant to some demographic variables. The research group consists of 146 physical education and sports teachers working in schools. Personal information forms, "Minnesota Satisfaction Questionnaire" and "Organizational Trust of School Scale" have been used as data collection tools. Pearson moments correlation coefficients have been tackled for the relationship between organizational trust and job satisfaction. It has been observed that there was a positive, significant relationship between job satisfaction and organizational trust in the research findings $(p<.05)$. As a result of the research, it has been predicted that factors such as the individual's location, psychological and environmental factors, working conditions, and communication have an active role in determining the relationship between job satisfaction and organizational trust.
\end{abstract}

Keywords: Physical Education; Job satisfaction; Organizational trust

Article History: Submitted 6 December 2020; Revised 26 February 2021; Published online 3 March 2021

\section{Introduction}

Although there are many universal definitions of job satisfaction in the field of literature, job satisfaction plays a decisive role in reaching a goal or not (Gruneberg, 1979; Parks \& Parra, 1994). Job satisfaction, which has a complex structure, have a relationship in many areas such as personal, social, cultural, environmental and financial factors (Stankovska et al., 2017). Job satisfaction is how satisfied employees are with their job (Furham et al., 2009) and how they feel about different aspects of jobs. Job satisfaction is how people feel about their job and different aspects of the job. Factors such as appreciation, business friendship, wage, rights other than salary, communication, staff growth, and security as parts of a job are expressed as common job satisfaction aspects (Spector, 1997). In job satisfaction, there will be no healthy interaction with management without the concept of satisfaction and it will cause personnel losses (Smucker et

Address of Corresponding Author

Murat Aygün, PhD, Ardahan University, School of Physical Education and Sports, Sports Management Sciences, 75002, Ardahan, Turkey.

$\triangle$ aygunmurat06@gmail.com

0000-0002-7636-8325

How to cite: Aygün, M. (2021). Analysis of the relationship between job satisfaction and organizational trust of physical education and sports teachers. Journal of Pedagogical Research, 5(1), 203-215. http://dx.doi.org/10.33902/JPR.2021167583 
al., 2003). Searching the concept of satisfaction is not only significant for the job attitude but also the job performance of the individual and the organization (Dixon \& Warner, 2010). Job satisfaction is welded from many interrelated, non-negligible factors such as personal, job and management control (Mishra, 2013). With this relationship, job satisfaction has a positive relationship with financial performance and organizational performance including service performance and behavioural performance (Shiu \& Yu, 2010). Job satisfaction as an academic concept has taken place in many different disciplines in recent years ( $\mathrm{Zhu}, 2013)$. In the field of sports management sciences, few studies have studied job satisfaction levels although the programs have grown (Hall, 2003). Some factors expressed concerning job satisfaction reveal the profile of the organization and the enterprise by highlighting the effectiveness of the individual within the enterprise.

In parallel with the perception and interpretation of organizational structures in different ways according to the professional and personal characteristics of individuals, the service quality of an organization may also depend on individual factors (Feeney \& Boardman, 2011). Behaviourist Abraham Maslow pointed out that we need to implicitly use our natural abilities and skills to be satisfied with our life and career (Wicker, 2011). The concept of trust has an important place in the use of skills and abilities. Scientists from many different disciplines have studied the cause, nature, and effects of trust.

"Trust is an expectancy of positive (or nonnegative) outcomes that one can receive based on the expected action of another party in an interaction characterized by uncertainty" (Bhattacharya et al., 1998). Scientists in many different disciplines have studied the cause, nature, and effects of trust. Although trust has been described in many different ways, the ambiguity and complexity of the concept between risk and trust cause insecurity in organizations (Mayer et al., 1995). The profile of an organization is expressed as an organizational culture in organizations. Components such as mission, environment, leadership, strategy, knowledge and socialization constitute the organizational culture framework (Tierney, 2008). Trust to the organization refers to the relationship established between employees and the organization (Fard \& Karimi, 2015). Any change may appear suspicious and anxious when there is little or no trust in the organization (Neves \& Caetano, 2006). The environment of trust and open communication are essential for an effective and productive work environment (Mishra \& Morrissey, 1990). In organizations or businesses, the high self-confidence of the individual is in line with performance since it will increase motivation (Benabou \& Tirole, 2002). Increasing or decreasing performance is notable for the development and in-house development of the organization.

For practical and theoretical reasons in organizations, the key element is to determine the relationships between the institution officials of the individual and the institutions represented by the authorities. The main purpose of the studies is to reveal the importance of trust for the organization by defining the conditions in which employees' trust in organizational authority, job attitude, and behaviour more or less related to the job (Brockner et al., 1997). Trust helps to expand the knowledge area since the trust environment improves service and employee satisfaction (Chathoth et al., 2007). Trust, which is effective for the results of the organization (Bidarian \& Jafari, 2012), helps the development of service and employee satisfaction and enables the expansion of the knowledge area (Chathoth et al., 2007). According to Brochner and Wiesenfeld (1996), while positive consequences can satisfy people due to individuals' result-oriented approach in the organization; negative results may cause more explanations (De Cremer, 2005). In many negative situations encountered in life, the ability of the individual to express himself/herself correctly will cause a positive transformation in a short time. This situation will cause a more detailed effect on institutions and organizations that have profit or service purposes. Therefore, while job satisfaction is achieved with effective communication within the company thanks to the employees of the institution or managers, the integrity of the individual within the organization will be successfully presented with self-confidence. 
Internal and external factors that we encounter in many areas have certain effects on our lives in many ways. Psychological factors, which have an important place in the impact process, help us learn the job satisfaction and organizational trust of working individuals. It is predicted that the constant interaction of the employees in the organization with other individuals will cause some feelings towards the institution they work with. This study aimed at analysing the relationship between job satisfaction and organizational trust of physical education and sports teachers. The objective of this study is to analyse the relationship between job satisfaction and organizational trust of physical education and sports teachers. It is foreseen that the development of teachers' sense of belonging and trust in the institution lead to the stronger progress of education, which is an important factor in social development It will be a guide in many areas where the concepts of education, sports management, and sports psychology are used. The interest of people and organizations in the work to be done to become successful brings many new studies.

\subsection{Theoretical Framework}

The trust model has gained prominence with the development of the concept of intercultural tendency, In the past decade, although there have been many kinds of research about trust, new studies only provide information about what needs to be done and which methods to be followed (Schoorman et al., 2007). Scientists have evaluated the cause, nature, and effects of trust from various disciplines. This evaluation has led to new research in many different fields and to reveal the reasons for the source of trust (Mayer et al., 1995). The main theme is to build trust as three dimensions in the organizational environment. These are called building trust, leadership and choice (Li, 2008). It is believed that the concept of trust will have an effect on organizational factors (Wiewiora et al., 2010) and will affect the relationship of trust (Mühl, 2014). Furthermore, organizational trust contributes to job satisfaction appertaining to participation (Driscoll, 1978). Job satisfaction cannot be completely understood without details about job conditions and professional development expectations (Olaskoaga-Larrauri et al., 2020). Fundamental psychological requirements that trigger teachers' professional satisfaction have been searched. In many studies, a sense of competence for the job has a vital role in the development of decisionmaking autonomy and professional satisfaction (Eirín-Nemiña et al., 2020). In general, researchers has divided job satisfaction into two groups as internal and external factors. While internal factors can be described as workmates and job themselves; external factors can be defined as payment and promotions (Judge \& Klinger, 2008).

In recent times, educational institutions are confronted with social, cultural, economic and political difficulties (Hoppes \& Holley, 2014). It is supposed that building a sense of trust in educational institutions will affect the whole society for a long period since it creates a positive effect within the institution and helps the individual gain positive behaviour (Artuksi, 2009). The important role of teachers 'organizational commitment to improving the quality of education has made it necessary to study teachers' organizational commitment (Pranitasari, 2020). Many research by educational institutions did not take sufficiently into consideration of human resource management, which is important for the development of the institution (Azarian \& Taghipour, 2020).

Consequentially, physical education and sports teachers have some features such as teaching and coaching that distinguish them from other teachers (Koustelios \& Tsigilis, 2005). The practicality of physical education and sports lessons and the prominence of physical skills make physical education and sports teachers different. Having an adequate level of physical education and sports teachers, job satisfaction and organizational trust positively affect the success of the educational institution. Thusly, the importance of job satisfaction and organizational trust for education are among the subjects studied within the scope of the research. 


\section{Method}

In this study, the correlational research method is used to analyse the relationship and level between variables since the relationship between job satisfaction and organizational trust has been studied without any intervention (Christensen et al., 2010; Fraenkel \& Wallen, 2006).

\subsection{Participants}

The study group includes 146 teachers who work as physical education and sports teachers in a province in the Northern East of Turkey. Certain knowledge of the study group is presented in Table 1.

Table 1

Demographic features

\begin{tabular}{llcc}
\hline Variables & & $\mathbf{N}$ & $\mathbf{\%}$ \\
\hline \multirow{2}{*}{ Gender } & Female & 41 & 28.1 \\
& Male & 105 & 71.9 \\
\hline \multirow{2}{*}{ Educational Institution } & Secondary School & 97 & 66.4 \\
& High School & 49 & 33.6 \\
\hline \multirow{2}{*}{ Workplace } & Province & 92 & 63.0 \\
& District & 54 & 37.0 \\
\cline { 2 - 4 } & Total & 146 & 100.0 \\
\hline
\end{tabular}

$28.1 \%$ of the teachers participating in the research are women and $71.9 \%$ are men. While $66.4 \%$ of them work in a secondary education institution, 33.6\% of them have a job occupation in high school. $63.0 \%$ of them are employed in the province and $37.0 \%$ work in the districts.

\subsection{Data Collection Tools}

Personal Information Form including demographic features, Minnesota Satisfaction Questionnaire (MSQ), and Organizational Trust of School Scale (OTSS) are used as data collection tools in this study.

\subsubsection{Personal Information Form (PIF)}

It is the form that includes the demographic variables of individuals created by the researchers. There are certain variables such as gender, educational institution, and workplace in this form.

\subsubsection{Minnesota Satisfaction Questionnaire (MSQ)}

This questionnaire was developed by Weiss et al. (1967) and adapted into Turkish by Baycan (1985). The measuring tool, which consists of a total of 20 items and two sub-dimensions, is of the 5-point Likert type. The answers on the scale are as follows: I am not happy at all (1), I am not satisfied (2), I am indecisive (3), I am satisfied (4) and I am very satisfied (5). The lowest score that can be obtained from the scale is 20 , the middle score is 60 , and the highest score is 100 . The higher the scores, the higher the overall job satisfaction. Above a middle score $(>60)$ is considered high job satisfaction, and below a middle score $(<60)$ is considered low job satisfaction. As the points obtained are high, general job satisfaction increases. Above a middle score $(>60)$ is considered high job satisfaction, and below a middle score $(<60)$ is considered low job satisfaction. The Minnesota Satisfaction Questionnaire (MSQ) has two sub-dimensions as internal and external factors (see Figure 1).

\subsubsection{Organizational Trust of School Scale (OTSS)}

This scale was developed by Daboval et al. (1994) and adapted by Yilmaz (2005) for educational institutions. The scale has four sub-dimensions and 40 questions. The Organizational Trust of School Scale to be used in the study is a 6-point Likert-type scale. It includes such answers: I totally agree (6), I strongly agree (5), I agree (4), I slightly agree (3), I disagree (2), I do not agree at all (1). 
Reliability coefficients range from 0.75 to 0.95 for all sub-dimensions.Organizational Trust of School Scale (OTSS) consists of 4 sub-dimensions: the sensibility to workers, trust to the administrator, openness to modernity, and communication climate.

The sub-dimensions of MSQ and OTSS scales are summarized in Figure 1.

Figure 1

Sub-dimensions of the scales
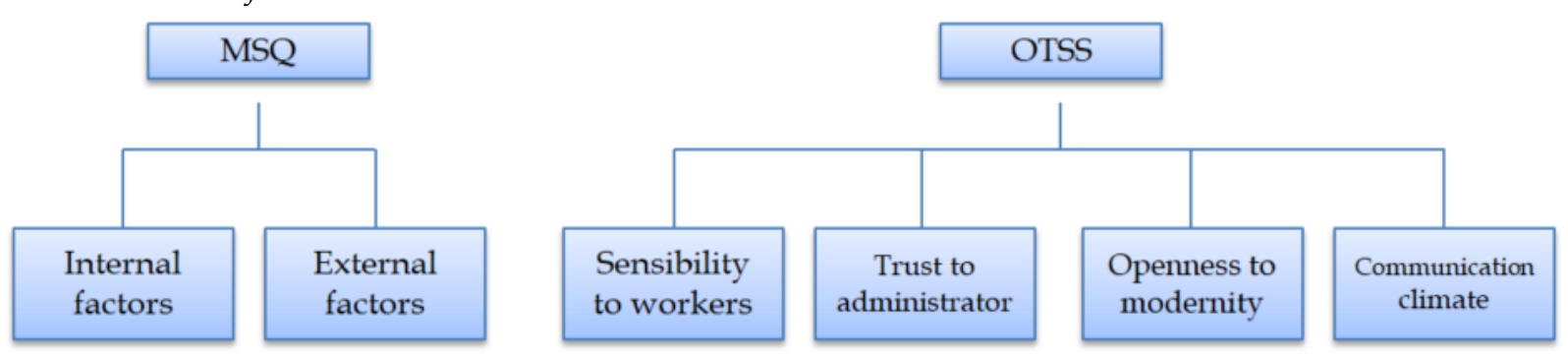

\subsection{Data Analysis}

Descriptive statistics regarding the demographic features of the teachers and the scores they gathered from the data collection tools are calculated. When the skewness and kurtosis values are analysed, the Skewness and Kurtosis values of the organizational trust and job satisfaction scale are between $-1 /+1$ (OTSS; Skewness: -.44 and Kurtosis: -.58 MSQ: Skewness: .79 and Kurtosis: 1.54). It is observed that the job satisfaction scale showed a more gross distribution than normal. As analysing the relationships between organizational trust and the sub-dimensions of job satisfaction, Pearson moments correlation coefficients are used.

\section{Results}

Information on the relationship between sub-dimensions considering various demographic variables of physical education and sports teachers participating in the study is presented in this section. The relationship between organizational trust and job satisfaction in schools is given in Table 2.

Table 2

Pearson Correlation Analysis unclosing the relationship between Organizational Trust and Job Satisfaction

\begin{tabular}{lccc}
\hline Variables & $n$ & 1 & 2 \\
\hline 1. OTSS & 146 & - & \\
2. MSQ & 146 & $.16^{*}$ & - \\
\hline
\end{tabular}

${ }^{*} p<.05$ OTSS= Organizational Trust of School Scale; MSQ= Minnesota Satisfaction Questionnaire

As can be seen in Table 2, the relationship between the participants' Organizational Trust of School Scale and Minnesota Satisfaction Questionnaire scores have been measured by Pearson correlation. A weak, positive and significant relationship has been identified between these variables $(r(144)=.16, p<.05)$. Findings regarding the correlation between organizational trust and job satisfaction sub-dimensions can be observed in Table 3.

It is clear from Table 3, while there is a positively and weakly non-significant relationship in "internal factors" from Job Satisfaction sub-dimensions and "sensibility to workers" $(r=.02)$, "openness to modernity" $(r=.00)$ and "communication climate" $(r=.05)$ from Organizational Trust of School sub-dimensions ( $\mathrm{p}>.05)$ for Physical Education and Sports Teacher; there is a negative and weak $(r=-.00)$ relationship with the "trust to administrator" sub-dimension $(p>.05)$. Furthermore, it is understood that there is a positively and medium level significant relation in 
Table 3

Pearson Correlation Analysis unclosing the relationship between Organizational Trust and Job Satisfaction

\begin{tabular}{lcclllll}
\hline Variables & $n$ & 1 & 2 & 3 & 4 & 5 & 6 \\
\hline 1. OTSS (Sensibility to workers) & 146 & - & & & & & \\
2. OTSS (Trust to the administrator) & 146 & $.88^{* *}$ & - & & & \\
3. OTSS (Openness to Modernity) & 146 & $.87^{* *}$ & $.97^{* *}$ & - & & \\
4. OTSS (Communication Climate) & 146 & $.85^{* *}$ & $.95^{* *}$ & $.95^{* *}$ & - & & \\
5. MSQ (Internal Factors) & 146 & .02 & -.00 & .00 & .05 & - & \\
6. MSQ (External Factors) & 146 & $.23^{*}$ & $.22^{*}$ & $.22^{*}$ & $.30^{* *}$ & $.52^{* *}$ & - \\
\hline${ }^{*} p<.05{ }^{* *} p<.001$ OTSS= Organizational Trust of School Scale; $M S Q=$ Minnesota Satisfaction Questionnaire
\end{tabular}

"external factors" from Job Satisfaction sub-dimensions and "sensibility to workers" $(r=.23)$, "trust to administrator" $(r=.22)$, "openness to modernity" $(r=.22)$ and "communication climate" $(r=.52)$ from Organizational Trust of School sub-dimensions $(p>.05, p<.001)$. The findings regarding the correlation between organizational trust and job satisfaction subdimensions in terms of gender variable are given in Table 4.

Table 4

Pearson Correlation Analysis unclosing the relationship between Organizational Trust and Job Satisfaction pursuant to Gender Variable

\begin{tabular}{|c|c|c|c|c|c|c|c|}
\hline Gender & Variables & 1 & 2 & 3 & 4 & 5 & 6 \\
\hline \multirow{6}{*}{ Male } & 1. OTSS (Sensibility to workers) & - & & & & & \\
\hline & 2. OTSS (Trust to the administrator) & $.86^{* *}$ & - & & & & \\
\hline & 3. OTSS (Openness to Modernity) & $.83^{* *}$ & $.97^{* *}$ & - & & & \\
\hline & 4. OTSS (Communication Climate) & $.80^{* *}$ & $.95^{* *}$ & $.94^{* *}$ & - & & \\
\hline & 5. MSQ (Internal Factors) & .07 & .04 & .04 & .11 & - & \\
\hline & 6. MSQ (External Factors) & $.25^{*}$ & $.25^{*}$ & $.25^{*}$ & $.32 * *$ & $.50 * *$ & - \\
\hline \multirow{6}{*}{ Female } & 1. OTSS (Sensibility to workers) & - & & & & & \\
\hline & 2. OTSS (Trust to the administrator) & $.91^{* *}$ & - & & & & \\
\hline & 3. OTSS (Openness to Modernity) & $.94^{* *}$ & $.97^{* *}$ & - & & & \\
\hline & 4. OTSS (Communication Climate) & $.92^{* *}$ & $.96^{* *}$ & $.96^{* *}$ & - & & \\
\hline & 5. MSQ (Internal Factors) & -.03 & -.08 & -.06 & -.04 & - & \\
\hline & 6. MSQ (External Factors) & .17 & .15 & .11 & .27 & $.58^{* *}$ & - \\
\hline
\end{tabular}

According to Table 4, there is a positive weakly non-significant relationship with "internal factors" from the job satisfaction sub-dimensions and "sensibility to workers" $(r=.07)$; "trust to administrator" ( $r=.04)$; "openness to modernity" $(r=.04)$ and "communication climate" $(r=.11)$ from organizational trust sub-dimensions on male teachers $(p<.05, p<.001)$. There is a negative weakly non-significant relationship with "internal factors" from the job satisfaction sub-dimensions and "sensibility to workers" ( $r=-.03)$; "trust to administrator" $(r=-.08)$; "openness to modernity" $(r=-.06)$ and "communication climate" $(r=-.04)$ from organizational trust sub-dimensions on female teachers working ( $p>05)$.

Moreover, there is a positive medium-level significant relationship with "internal factors" from the job satisfaction sub-dimensions and "sensibility to workers" $(r=.25)$; "trust to administrator" $(r=.25)$; "openness to modernity" $(r=.25)$ and "communication climate" $(r=.32)$ from organizational trust sub-dimensions on male teachers $(\mathrm{p}<.05, \mathrm{p}<.001)$. There is a positive weakly non-significant relationship with "external factors" from the job satisfaction sub-dimensions and "sensibility to workers" $(r=.17)$; "trust to administrator" $(r=.15)$; "openness to modernity" $(r=.11)$ and "communication climate" $(r=.27)$ from organizational trust sub-dimensions on female teachers $(p>.05)$. The findings regarding the correlation between organizational trust and 
job satisfaction sub-dimensions in terms of the institution variable they work for are given in Table 5.

Table 5

Pearson Correlation Analysis unclosing the relationship between Organizational Trust and Job Satisfaction pursuant to Educational Institution Variable

\begin{tabular}{llllllll}
\hline Educational Institution & Variables & 1 & 2 & 3 & 4 & 5 & 6 \\
\hline & 1. OTSS (Sensibility to workers) & - & & & & & \\
& 2. OTSS (Trust to the administrator) & $.88^{* *}$ & - & & & & \\
3. OTSS (Openness to Modernity) & $.86^{* *}$ & $.97^{* *}$ & - & & & \\
& 3econdary School & & & & & \\
& 4. OTSS (Communication Climate) & $.83^{* *}$ & $.95^{* *}$ & $.96^{* *}$ & - & & \\
& 5. MSQ (Internal Factors) & -.17 & -.16 & -.14 & -.12 & - & \\
& 6. MSQ (External Factors) & .10 & .15 & .13 & $.22^{*}$ & $.44^{* *}$ & - \\
\hline & 1. OTSS (Sensibility to workers) & - & & & & & \\
& 2. OTSS (Trust to the administrator) & $.91^{* *}$ & - & & & & \\
3. OTSS (Openness to Modernity) & $.90^{* *}$ & $.97^{* *}$ & - & & & \\
& 4igh School & & & & & \\
& 4. OTSS (Communication Climate) & $.92^{*}$ & $.96^{*}$ & $.96^{*}$ & - & & \\
& 5. MSQ (Internal Factors) & $.33^{*}$ & .23 & .24 & $.31^{*}$ & - & \\
& 6. MSQ (External Factors) & $.45^{* *}$ & $.35^{*}$ & $.37^{*}$ & $.42^{*}$ & $.61^{* *}$ & - \\
\hline
\end{tabular}

${ }^{*} p<.05 \quad * * p<.001$ OTSS= Organizational Trust of School Scale; MSQ= Minnesota Satisfaction Questionnaire

Considering the information on Table 5, it can be expressed that there is a negative weakly nonsignificant relationship with "internal factors" from the job satisfaction sub-dimensions and "sensibility to workers" $(r=-.17)$; "trust to administrator" $(r=-.16)$; "openness to modernity" $(r=-.14)$ and "communication climate" $(r=-.12)$ from organizational trust sub-dimensions on teachers working in secondary schools $(p>.05)$. There is a positive, medium-level significant relationship with "internal factors" from the job satisfaction sub-dimensions and "sensibility to workers" $(r=.33)$ and "communication climate" $(r=.31)$ from organizational trust sub-dimensions on teachers working in the high schools $(\mathrm{p}>.05)$.

While there is a positive and weakly non-significant relationship in the sub-dimensions of "external factors" from the job satisfaction sub-dimension and "sensibility to workers" $(r=.10)$; "trust to administrator" $(r=.15)$ and "openness to modernity" ( $r=.13)$ from organizational trust sub-dimensions $(p>.05)$, there is a positive and weakly significant relationship $(p<.05)$ in the "communication climate" $(r=.22)$ sub-dimension on the teachers working in secondary schools. There is a positive, medium-level significant relationship with "external factors" from the job satisfaction sub-dimensions and "sensibility to workers" $(r=.45)$; "trust to administrator" ( $r=.35)$; "openness to modernity" $(\mathrm{r}=.37)$ and "communication climate" $(r=.42)$ from organizational trust sub-dimensions on teachers working in high schools $(\mathrm{p}<.05, \mathrm{p}<.001)$. The findings regarding the correlation between organizational trust and job satisfaction sub-dimensions in terms of workplace variables are given in Table 6.

As it can be seen in Table 6, there is a positive, weakly non-significant relationship with "internal factors" from the job satisfaction sub-dimensions and "sensibility to workers" $(r=.12)$; "trust to administrator" ( $r=.07)$; "openness to modernity" $(r=.04)$ and "communication climate" $(r=.12)$ from organizational trust sub-dimensions on teachers working in the province ( $\mathrm{p}>.05)$. There is a weakly non-significant relationship in the negative direction in the sub-dimensions of "internal factors" from the job satisfaction sub-dimensions and "sensibility to workers" ( $r=-.07)$, trust to administrator" ( $r=-.09)$; "openness to modernity" $(r=-.03)$ and "communication climate" $(r=-.00)$ from organizational trust sub-dimensions on the teachers working in the districts $(\mathrm{p}>.05)$. 
Table 6

Pearson Correlation Analysis unclosing the relationship between Organizational Trust and Job Satisfaction pursuant to Workplace Variable

\begin{tabular}{|c|c|c|c|c|c|c|c|}
\hline Workplace & Variables & 1 & 2 & 3 & 4 & 5 & 6 \\
\hline \multirow{6}{*}{ Province } & 1. OTSS (Sensibility to workers) & - & & & & & \\
\hline & 2. OTSS (Trust to the administrator) & $.83^{* *}$ & - & & & & \\
\hline & 3. OTSS (Opennes to Modernity) & $.81^{* *}$ & $.96^{* *}$ & - & & & \\
\hline & 4. OTSS (Communication Climate) & $.80^{* *}$ & $.94^{* *}$ & $.94^{* *}$ & - & & \\
\hline & 5. MSQ (Internal Factors) & .12 & .07 & .04 & .12 & - & \\
\hline & 6. MSQ (External Factors) & $.30 * *$ & $.29 * *$ & $.28^{* *}$ & $.43^{* *}$ & $.55^{* *}$ & - \\
\hline \multirow{6}{*}{ District } & 1. OTSS (Sensibility to workers) & - & & & & & \\
\hline & 2. OTSS (Trust to the administrator) & $.95^{* *}$ & - & & & & \\
\hline & 3. OTSS (Openness to Modernity) & $.95^{* *}$ & $.98^{* *}$ & - & & & \\
\hline & 4. OTSS (Communication Climate) & $.91^{* *}$ & $.98^{* *}$ & $.97^{* *}$ & - & & \\
\hline & 5. MSQ (Internal Factors) & -.07 & -.09 & -.03 & -.00 & - & \\
\hline & 6. MSQ (External Factors) & .09 & .07 & .06 & .00 & $.52^{* *}$ & - \\
\hline
\end{tabular}

There is a positive, medium-level significant relationship with "external factors" from the job satisfaction sub-dimensions and "sensibility to workers" $(r=.30)$; "trust to administrator" $(r=.29)$; "openness to modernity" ( $r=.28)$ and "communication climate" $(r=.42)$ from organizational trust sub-dimensions on teachers working in the province $(\mathrm{p}<.001)$. There is a positive and weakly nonsignificant relationship in the sub-dimensions of "external factors" from the job satisfaction subdimensions and "sensibility to workers" ( $r=.09)$; "trust to administrator" $(r=.07)$, "openness to modernity" ( $r=.06)$ and "communication climate" $(r=.00)$ from organizational trust subdimensions on the teachers working in the districts $(p>.05)$.

\section{Discussion and Conclusion}

In the study, it has been manifested that there is a positive and significant relationship between job satisfaction and organizational trust of physical education and sports teachers. It is believed that this result will have a positive effect on job satisfaction and increase the individual's sense of trust in the institution. Rowden's (2002) study on the relationship between learning and job satisfaction, it was revealed that learning in the workplace is related to job satisfaction. Existing studies in the literature revealed that various factors such as organizational support (Afif, 2018), quality management (Azarian \&Taghipour, 2020), organizational commitment (Baştuğ et al., 2016), leadership (Boyac1 et al., 2018; Megheirkouni, 2018), employee satisfaction (Chathoth et al., 2007), learning (Chiang \& Wang, 2008; Rowden \& Ahmad, 2000), emotional intelligence (Chiva \& Alegre, 2008), trust (Çelebi \& Tatık, 2019; Khany \& Tazik, 2016; Saridakis et al., 2020; Srivastava, 2013), motivation (Egan et al., 2004), organizational silence (Fard \& Karimi, 2015), work performance (Mouloud et al., 2016), commitment (Rose et al., 2009), and physical capital (Shamhi et al., 2018) are effective on job satisfaction and organizational trust. Koustelios and Tsigilis (2005) emphasized that the internal aspects of job satisfaction are stronger than the external ones. Moreover, they have claimed that work commitment is important for the formation of qualified education staff. In a study on physical education and sports teachers by Mousavi et al. (2012), emotional intelligence, motivation, empathy and social skills are related to job satisfaction. This is because factors such as speaking and communication skills in physical education and sports teachers are effective in group work. Demirtaş (2010) pointed out that high job satisfaction has a positive effect on the realization of educational goals and as a consequence, qualified and successful students can be raised. While Usop et al. (2013) figured that when teachers are satisfied with their jobs, their job satisfaction will increase and also the salary, success and 
responsibility are important for their job satisfaction; İscan and Sayın (2010) emphasized that the decisions taken in setting relationships based on trust in an institution should be fair and the level of satisfaction should be high. It is thought that the satisfaction and sense of trust of the personnel resource, which has an important place in the success of many institutions, is an important factor in the similarity of the studies with our study.

The lack of adequate coverage of variables such as gender, institution, and place of duty between job satisfaction and organizational trust in the field literature has increased the importance of the study. In our research, while there is no relationship between internal factors and organizational trust; there is a significant relationship between external factors and organizational trust in terms of gender variable on male teachers. Moreover, there is no significant relationship between organizational trust sub-dimensions of internal and external factors on the female teacher. Thus, it is thought that this situation will not affect job satisfaction. Çelebi and Tatık's (2019) study on the prediction of the level of job satisfaction of teachers on the perception of organizational trust of teachers displays that there is no significant relationship between gender variable and job satisfaction. It is claimed that Zeinabadi and Salehi's study (2011) was partially similar to job satisfaction and organizational commitment, and gender was an important factor in the job behaviours of Kidder and Parks's study (2001). Bender et al. (2005) proved that the job satisfaction of women is a more important factor in job satisfaction according to gender differences than traditionally female-dominated institutions. Ross et al. (2014) expressed that although gender is not important in job satisfaction, the position and duration of duty are considered as factors in that situation. The fact that there are few female physical education and sports teachers in the sample group of the study can be accounted for the result of this condition and the lack of confidence in themselves and the organization.

In terms of the institution they work for the variable, there is no relationship between internal factors and organizational trust but there is a significant relationship between external factors and organizational trust sub-dimension of "communication climate" on the teachers in secondary schools. For teachers working in high school, it is enounced that there is a significant relationship between the "sensibility to workers and the communication climate" sub-dimension of internal factors, and also there is a significant relationship between organizational trust sub-dimensions of external factors. It has been observed that the relationship between organizational trust and job satisfaction of high school teachers is higher than teachers working in secondary education. In the literature, Hulpia et al. (2009) found a significant relationship between two variables in their study on job satisfaction and organizational commitment in secondary schools. Additionally, leadership behaviour of teachers working in secondary education (Demir, 2015); and social support (Taşdan \& Yalçın., 2010) was found to be related to organizational trust. Öztürk and Aydın (2012) stated that teachers working in secondary education institutions have a high level of trust in the institution and the communication dimension is important. Kars and Inand1 (2018) noted that administrators should deal with the problems of teachers and be more transparent and decisive in their actions to create a sense of trust in the school. According to the findings of our research, it is believed that the coexistence of teachers who teach in different branches due to the type of educational institution of high school teachers, communication is stronger and the emphasis on teachers' feelings and thoughts within the institution will determine the relationship of organizational trust with job satisfaction.

It has been observed that the work on the relationship between job satisfaction and organizational trust is not at a sufficient level in terms of workplace variables. There is a significant relationship between external factors and organizational trust. There is no significant relationship between the organizational trust sub-dimensions of internal and external factors for teachers working in the district. When the factors such as the fact that the teachers working in the districts do not live where their families or peer groups are located, the life situations and social activities are not at a sufficient level according to the provinces are taken into consideration, it is 
thought that there is no sense of trust in the organization and as a result, job satisfaction will not be achieved.

It is supposed that living conditions, internal communication, institutional duties, physical and social characteristics of the province or district where organizational trust is created will cause trust in the organization and affect job satisfaction at a positive and significant level. Considering the literature, it is thought that this study will shed light on new studies and sports science since there is no similar study on the relationship between job satisfaction and organizational trust of physical education and sports teachers. Regarding that the relationship between job satisfaction and organizational trust may change, it is suggested to be done on different demographic variables and sample groups. Numerous studies to be conducted with different variables will be important in determining the relationship between physical education and sports teachers' job satisfaction and organizational trust.

Acknowledgement. Within the scope of the study, the ethics committee decision numbered E-67796128-000-2100002240 by Ardahan University Scientific Publication and Ethics Committee and the questionnaire application permission numbered E-36648235-605.01-20525076 were obtained from Erzurum Provincial Directorate of National Education.

\section{References}

Afif, A. H. (2018). The relationship between perceived organizational supports with job satisfaction and organizational commitment at faculty members of universities. Sleep and Hypnosis, 20(4), 290-293. https://doi.org/10.5350/Sleep.Hypn.2018.20.0164

Artuksi, E. (2009). Primary school assistant teacher in the school of organizational trust level on the perception [Unpublished master's thesis]. Inonu University, Malatya, Turkey.

Azarian, R., \& Taghipour, M. (2020). The impact of implementing inclusive quality management on organizational trust (Case Study: Education). Journal of Multidisciplinary Engineering Science Studies, 6(7), 3376-3383.

Baştuğ, G., Pala, A., Kumartaşli, M., Günel, İ., \& Duyan, M. (2016). Investigation of the relationship between organizational trust and organizational commitment. Universal Journal of Educational Research, 4(6), 14181425. https:// doi.org/10.13189/ujer.2016.040619

Baycan, A. (1985). An analysis of the several aspects of job satisfaction between different occupational groups [Unpublished master's thesis]. Boğaziçi University, İstanbul, Turkey.

Benabou, R., \& Tirole, J. (2002). Self-confidence and personal motivation. The Quarterly Journal of Economics, 117(3), 871-915. https:// doi.org/10.1162/003355302760193913

Bender, K. A., Donohue, S. M., \& Heywood, J. S. (2005). Job satisfaction and gender segregation. Oxford Economic Papers, 57(3), 479-496. https://doi.org/10.1093/oep/gpi015

Bhattacharya, R., Devinney, T. M., \& Pillutla, M. M. (1998). A formal model of trust based on outcomes. Academy of Management Review, 23(3), 459-472. https:// doi.org/10.5465/amr.1998.926621

Bidarian, S., \& Jafari, P. (2012). The relationship between organizational justice and organizational trust. Procedia-Social and Behavioral Sciences, 47, 1622-1626. https://doi.org/10.1016/j.sbspro.2012.06.873

Boyac1, A., Karacabey, M. F., \& Bozkuş, K. (2018). The role of organizational trust in the effect of the leadership of school administrators on the job satisfaction of teachers. Educational Administration: Theory and Practice, 24(3), 437-482. https:// doi.org/10.14527/kuey.2018.011

Brockner, J., \& Wiesenfeld, B.M. (1996). An integrative framework for explaining reactions to decisions: Interactive effects of outcomes and procedures. Psychological Bulletin, 120(2), 189-208. https://doi.org/10.1037/0033-2909.120.2.189

Brockner, J., Siegel, P., Daly, J., Tyler, T., \& Martin, C. (1997). When trust matters: the moderating effect of outcome favorability. Administrative Science Quarterly, 42(3), 558-583. https://doi.org/10.2307/2393738

Chathoth, P. K., Mak, B., Jauhari, V., \& Manaktola, K. (2007). Employees' perceptions of organizational trust and service climate: a structural model combining their effects on employee satisfaction. Journal of Hospitality \& Tourism Research, 31(3), 338-357. https://doi.org/10.1177/1096348007299922

Chiang, T., \& Wang, J. (2008). Workplace learning, job satisfaction, and organizational commitment in small to midsize companies in Taiwan. Paper presented at the Academy of Human Resources Development International Research Conference in the Americas, Panama City, Florida. 
Chiva, R., \& Alegre, J. (2008). Emotional intelligence and job satisfaction: the role of organizational learning capability. Personnel Review, 36(6), 680-701. https://doi.org/10.1108/00483480810906900

Christensen, B. L., Johnson, R. B., \& Turner, L. A. (2011). Research methods, design and analysis. Pearson.

Çelebi, N., \& Tatık, R. Ş. (2019). Prediction of the level of job satisfaction of teachers on the perception of organizational trust of teachers: the study of regression analysis. Kastamonu Education Journal, 27(5), 21032114. https:// doi.org/10.24106/kefdergi.3324

Daboval, J., Comish, R., Swindle, B., \& Gaster, W. (1994). A trusted inventory for small businesses. Paper presented at the Conference of the Business Trends and Small Business Trust, Southwestern Small Business Institute Association, Dallas.

De Cremer, D. (2005). Procedural and distributive justice effects moderated by organizational identification. Journal of Managerial Psychology, 20(1), 4-13. https:// doi.org/10.1108/02683940510571603

Demir, K. (2015). The effect of organizational trust on the culture of teacher leadership in primary schools. Educational Sciences: Theory \& Practice, 15(3), 621-634. https://doi.org/10.12738/estp.2015.3.2337

Demirtas, Z. (2010). Teachers' job satisfaction levels. Procedia-Social and Behavioral Sciences, 9, 1069-1073. https://doi.org/10.1016/j.sbspro.2010.12.287

Dixon, M. A., \& Warner, S. (2010). Employee satisfaction in sport: development of a multi-dimensional model in coaching. Journal of Sport Management, 24, 139-168. https://doi.org/10.1123/jsm.24.2.139

Driscoll, J W. (1978). Trust and participation in organizational decision making as predictors of satisfaction. Academy of Management Journal, 21(1), 44-56. https:/ / doi.org/10.1177/105960117800300422

Egan, T. M., Yang, B., \& Bartlett, K. R. (2004). The effects of organizational learning culture and job satisfaction on motivation to transfer learning and turnover intention. Human Resource Development Quarterly, 15(3), 279-301. https:// doi.org/10.1002/hrdq.1104

Eirín-Nemiña, R., Sanmiguel-Rodríguez, A., \& Rodríguez-Rodríguez, J. (2020). Professional satisfaction of physical education teachers. Sport, Education and Society, 1-14. https://doi.org/10.1080/13573322.2020.1816540

Fard, P. G., \& Karimi, F. (2015). The relationship between organizational trust and organizational silence with job satisfaction and organizational commitment of the employees of university. International Education Studies, 8(11), 219-227. https:// doi.org/10.5539/ies.v8n11p219

Feeney, M. K., \& Boardman, C. (2011). Organizational confidence: an empirical assessment of highly positive public managers. Journal of Public Administration Research and Theory, 21(4), 673-697. https://doi.org/10.1093/jopart/muq044

Fraenkel, J. R., \& Wallen, N. E. (2006). How to design and evaluate research in education (6th ed.). McGraw-Hill.

Furnham, A., Eracleous, A., \& Chamorro-Premuzic, T. (2009). Personality, motivation and job satisfaction: Hertzberg meets the Big Five. Journal of Managerial Psychology, 24(8), 765-779. https://doi.org/10.1108/02683940910996789

Gruneberg, M. (1979). Understanding job satisfaction. MacMillan

Hall, C. (2003). Job satisfaction of sport management faculty in the USA (Unpublished doctoral dissertation). Florida State University, Tallahassee, FL.

Hoppes, C. R., \& Holley, K. A. (2013). Organizational trust in times of challenge: the impact on faculty and administrators. Innovative Higher Education, 39(3), 201-216. https:/ / doi.org/10.1007/ s10755-013-9275-y

Hulpia, H., Devos, G., \& Rosseel, Y. (2009). The relationship between the perception of distributed leadership in secondary schools and teachers' and teacher leaders' job satisfaction and organizational commitment. School Effectiveness and School Improvement, 20(3), 291-317. https:// doi.org/10.1080/09243450902909840

İşcan, Ö. F., \& Sayın, U. (2020). The relationship between organizational justice, job satisfaction and organizational trust. Journal of Economics and Administrative Sciences, 24(4), 195-216.

Judge, T. A., \& Klinger, R. (2008). Job satisfaction. Eid, M \& Larsen, R. J. (eds.), The science of subjective wellbeing. Guilford

Kars, M., \& Inand1, Y. (2018). Relationship between school principals' leadership behaviors and teachers' organizational trust. Eurasian Journal of Educational Research, 74, 145-164. https://doi.org/10.14689/ ejer.2018.74.8

Khany, R., \& Tazik, K. (2016). On the relationship between psychological empowerment, trust, and uranian efl teachers' job satisfaction: the case of secondary school teachers. Journal of Career Assessment, 24(1), 112129. https://doi.org/10.1177/1069072714565362

Kidder, D. L., \& Parks, J. M. (2001). The good soldier: who is s(he)? Journal of Organizational Behavior, 22(8), 939-959. https://doi.org/10.1002/job.119 
Koustelios, A., \& Tsigilis, N. (2005). The relationship between burnout and job satisfaction among physical education teachers: a multivariate approach. European Physical Education Review, 11(2), 189-203. https:// doi.org/10.1177/1356336x05052896

Li, P. P. (2008). Toward a geocentric framework of trust: an application to organizational trust. Management and Organization Review, 4(3), 413-439. https:// doi.org/10.1111/j.1740-8784.2008.00120.x

Mayer, R. C., Davis, J. H., \& Schoorman, F. D. (1995). An integratıve model of organizational trust. Academy of Management Review, 20(3), 709-734. https://doi.org/10.5465/amr.1995.9508080335

Megheirkouni, M. (2018). Power bases and job satisfaction in sports organizations. Journal of Global Sport Management, 4(3), 271-290. https:// doi.org/10.1080/24704067.2018.1442238

Mishra, J., \& Morrissey, M. A. (1990). Trust in employee/employer relationships: a survey of west michigan managers. Public Personnel Management, 19(4), 443-486. https://doi.org/10.1177/009102609001900408

Mishra, P. K. (2013). Job satisfaction. IOSR Journal Of Humanities And Social Science, 14(5), 45-54. https://doi.org/10.9790/1959-145455z

Mouloud, K., Bougherra, B., \& Samir, B. F. (2016). Job satisfaction for physical education teachers and its relationship to job performance and organizational commitment. Pedagogics, Psychology, Medical-Biological Problems Of Physical Training And Sports, 3, 47-51. https:/ / doi.org/10.15561/18189172.2016.0307

Mousavi, S. H., Yarmohammadi, S., Nosrat, A. B., \& Tarasi, Z. (2012). The relationship between emotional intelligence and job satisfaction of physical education teachers. Annals of Biological Research, 3(2), 780-788.

Mühl, J. K. (2014). Organizational trust. Springer.

Neves, P., \& Caetano, A., 2006. Social exchange processes in organizational change: the role of trust and control. Journal of Change Management, 6(4), 351-364. https:// doi.org/10.1080/14697010601054008

Olaskoaga-Larrauri, J., Rodríguez-Armenta, C. E., \& Marúm-Espinosa, E. (2020). The direction of reforms and job satisfaction among teaching staff in higher education in Mexico. Teaching in Higher Education, 117. https:// doi.org/10.1080/13562517.2020.1819225

Öztürk, Ç., \& Aydın, B. (2012). High school teachers' perceptions of trust in organization. Gaziantep University Journal of Social Sciences, 11(2), 485-504.

Parks, J. B., \& Parra, L. F. (1994). Job satisfaction of sport management alumnae/i. Journal of Sport Managemeni, 8, 49-56. https://doi.org/10.1123/jsm.8.1.49

Pranitasari, D. (2020). The influence of effective leadership and organizational trust to teacher's work motvation and organizational commitment. Media Ekonomi dan Manajemen, 35(1), 75-91. https://doi.org/10.24856/mem.v35i1.1257

Rose, R. C., Kumar, N., \& Pak, O. G. (2009). The effect of organizational learning on organizational commitment, job satisfaction and work performance. Journal of Applied Business Research (JABR), 25(6), 5566. https://doi.org/10.19030/jabr.v25i6.995

Ross, C. M., Young, S. J., Sturts, J. R., \& Kim, K. T. (2014). Personal correlates impacting job satisfaction among campus recreational sport employees. International Journal of Sport Management, Recreation $\mathcal{E}$ Tourism, 14, 68-97. https:// doi.org/10.5199/ijsmart-1791-874X-14d

Rowden, R. W. (2002). The relationship between workplace learning and job satisfaction in U.S. small to midsize businesses. Human Resource Development Quarterly, 13(4), 407-425. https://doi.org/10.1002/hrdq.1041

Rowden, R. W., \& Ahmad, S. (2000). The relationship between workplace learning and job satisfaction in small to mid-sized businesses in Malaysia. Human Resource Development International, 3(3), 307-322. https://doi.org/10.1080/13678860050128492

Saridakis, G., Lai, Y., Muñoz Torres, R. I., \& Gourlay, S. (2018). Exploring the relationship between job satisfaction and organizational commitment: an instrumental variable approach. The International Journal of Human Resource Management, 31(13), 1739-1769. https:/ / doi.org/10.1080/09585192.2017.1423100

Schoorman, F. D., Mayer, R. C., \& Davis, J. H., (2007). An integrative model of organizational trust: past, present and future. Academy of Management Review, 32(2), 344-354. https://doi.org/10.5465/AMR.2007.24348410

Shamhi, H., Vesisi, K., Hatami, K., \& Aliabadi, S. (2019). An investigation and modeling of the intermediary role of psychological capital in the relationship between organizational trust and job performance. PODIUM Sport, Leisure And Tourism Review, 8(1), 45-56. https:/ / doi.org/10.5585/podium.v8i1.320

Shiu Y. M., \& Yu T. W. (2010) Internal marketing, organizational culture, job satisfaction, and organizational performance in non-life insurance. Service Industries Journal, 30(6), 793-809. https://doi.org/10.1080/02642060701849840 
Smucker, M. K., Whisenant, W. A., \& Pedersen, P.M. (2003). An investigation of job satisfaction and female sports journalists. Sex Roles, 48(7/8), 401-407. https:// doi.org/10.1023/ A:1025120406343

Spector, P. E. (1997). Job satisfaction. Sage Publications.

Srivastava, S. (2013). Job satisfaction and organizational commitment relationship: effect of personality variables. Vision: The Journal of Business Perspective, 17(2), 159-167. https://doi.org/10.1177/0972262912483529

Stankovska, G., Angelkoska, S., Osmani, F., \& Grncarovska, S. P. (2017). Job motivation and job satisfaction among academic staff in higher education. Bulgarian Comparative Education Society, 15, 159-166.

Taşdan, M., \& Yalçın, T. (2010). Relationship between primary school teachers' perceived social support and organizational trust level. Educational Sciences: Theory and Practice, 10(4), 2609-2620.

Tierney, W. G. (2008). Trust and organizational culture in higher education. Valimaa, J. \& Ylijoki, O. H. (eds.), Cultural Perspectives on Higher Education (pp.27-41). Springer. https://doi.org/10.1007/978-1-40206604-7_3

Usop, A. M., Askandar, K., Langguyuan-Kadtong, M., \& Usop, D. A. S. O. (2013). Work performance and job satisfaction among teachers. International Journal of Humanities and Social Science, 3(5), 245-252.

Weiss, D. J., Dawis, R. V., England, G., \& Lofquist, L. H. (1967). Manual for the minnesota satisfaction questionnaire. Minnesota Studies in Vocational Rehabilitation, XXII.

Wicker, D. (2011). Job satisfaction: fact or fiction. AuthowHouse.

Wiewiora, A., Murphy, G. D., \& Trigunarsyah, B. (2010). The role of trust in inter-project knowledge transfer. Paper presented at the ICOMS Asset Management Conference Adelaide, Adelaide, Australia. https://doi.org/10.13140/2.1.3415.6800

Yllmaz, E. (2005). Validity and Reliability study of the Organizational Trust of School Scale. Selçuk University Journal of Graduate School of Social Sciences, 14, 567-580.

Zeinabadi, H., \& Salehi, K. (2011). Role of procedural justice, trust, job satisfaction, and organizational commitment in Organizational Citizenship Behavior (OCB) of teachers: Proposing a modified social exchange model. Procedia-Social and Behavioral Sciences, 29, 1472-1481. https://doi.org/10.1016/j.sbspro.2011.11.387

Zhu, Y. (2013). A review of job satisfaction. Asian Social Science, 9(1), 292-298. https://doi.org/10.5539/ass.v9n1p293 